\title{
Parathyroid Lesions: Our Single-Center Experience for the Last 5 Years
}

\author{
Paratiroid Lezyonları: Son 5 Yıllık Tek Merkez \\ Deneyimimiz
}

\author{
Özgün Araştırma \\ Research Article \\ Sümeyye Ekmekci $\odot$, Mehmet Üstün $\odot$, Yasemen Adalı $\odot$, Semra Demirli Atıcı $\odot$, \\ Ülkü Küçük $\odot$, Emel Ebru Pala $\odot$
}

\begin{abstract}
Objective: Parathyroid neoplasms are tumors seen in about $0.1 \%$ of the population. Although parathyroid adenomas are the most common, rarely carcinomas are also seen. Our aim in this study is to evaluate the clinical, laboratory and histopathological characteristics of patients who underwent parathyroidectomy in our hospital in the last 5 years.

Method: A total of 156 patients who underwent parathyroidectomy in our hospital and examined in the pathology department were included in the study. Cases were grouped according to the types of operations performed as those who underwent only parathyroid excision or partial/total thyroid excision with parathyroid excision. Age, gender, pre-and post-operative parathyroid hormone values, size, weight, pathological diagnosis of the parathyroid gland, presence of complications, comorbidities and their clinical follow-ups were evaluated.

Results: The $84 \%$ of 156 cases were female, and $16 \%$ were male. The mean age of the patients was $53.82 \pm 13.49$ years. The mean pre-, and post-operative parathyroid hormone levels of the cases were $415.18 \pm 491.15 \mathrm{mg} / \mathrm{dl}$, and $64.02 \pm 110.72 \mathrm{mg} / \mathrm{dl}$, respectively. The mean volume of parathyroid tissues was calculated as $5.13 \pm 8.85$ and the mean weight as $2.78 \pm 2.88 \mathrm{~g}$. Pathological diagnoses were adenoma in $83.3 \%$, hyperplasia in $10.9 \%$, atypical adenoma in $2.6 \%$, carcinoma in $1.9 \%$, normal parathyroid gland in $0.6 \%$ and lymph node in $0.6 \%$, of the cases. It was observed that as the postoperative PTH level increased, the weight of the parathyroid gland increased and the weight of the lesion was higher in males. The addition of thyroidectomy to the treatment, conventional parathyroidectomy instead of the minimally invasive method, and the high size and volume of the parathyroid gland were found to be associated with complications in the postoperative period.

Conclusion: In terms of thyroid pathologies that may accompany, it will be more appropriate to evaluate preoperative cases in detail and to continue the treatment with minimally invasive methods for the comfort of the patient in postoperative processes. It is highly important to always take a multidisciplinary management in the approach to parathyroid masses and to evaluate the clinical, laboratory, intraoperative and pathological findings of the cases in combination.
\end{abstract}

Received/Geliş: 29.01.2021

Accepted/Kabul: 02.02.2021

Published Online: 18.08.2021

Sümeyye Ekmekci Sağlık Bilimleri Üniversitesi Tepecik Eğitim ve Araştırma Hastanesi, Patoloji Bölümü, izmir - Türkiye

ekmekcisumeyye@gmail.com ORCID: 0000-0003-1607-500X

Ü. Küçük 0000-0003-2916-0123

E.E. Pala 0000-0001-7262-1867 Sağlık Bilimleri Üniversitesi Tepecik Eğitim ve Araştırma Hastanesi, Patoloji Bölümü, Izmir, Türkiye

M. Üstün 0000-0003-2646-5239 S. Demirli Atıcl 0000-0002-8287-067X Sağlık Bilimleri Üniversitesi Tepecik Eğitim ve Araştırma Hastanesi, Genel Cerrahi Bölümü, izmir, Türkiye

Y. Adalı 0000-0002-8004-7364 izmir Ekonomi Üniversitesi Tip Fakültesi, Patoloji Anabilim Dalı, Izmir, Türkiye

Cite as: Ekmekci S, Üstün M, Adalı Y, Demirli AtıcI S, Küçük Ü, Pala EE. Parathyroid Lesions: Our single-center experience for the last 5 years. Tepecik Eğit. ve Araşt. Hast. Dergisi. 2021;31(2):154-61.

Keywords: Parathyroid, adenoma, atypical, parathyroid carcinoma, neoplasia, parathyroid hormone

\section{öz}

Amaç: Paratiroid neoplaziler toplumda yaklaşık \%0,1 oranında görülen tümörlerdir. En sık paratiroid adenomları görülmekle birlikte çok nadiren karsinomları da izlenmektedir. Bu çalıșmada amacımız hastanemizde son 5 yılda paratiroidektomi yapılan olguların klinik, laboratuvar ve histopatolojik özelliklerini değerlendirmektir.

Yöntem: Çalışmaya hastanemizde paratiroidektomi yapılan ve patoloji bölümünde incelenen 156 olgu dahil edildi. Olgular uygulanan operasyon türleri yalnızca paratiroid eksizyonu yapılanlar ve paratiroid eksizyonu ile birlikte tiroid parsiyel/ total eksizyonu yapılanlar olarak gruplandırıldı. Olgulara ait yas, cinsiyet, pre ve post operatatif parathormon değerleri, paratiroid bezinin boyut, ağırlık, patolojik tanısı, komplikasyon varlığı, eșlik eden ek hastalıklar ve klinik takipleri değerlendirilmistir.

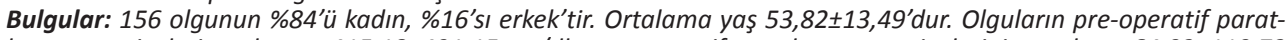
hormon seviyeleriortalaması $415,18 \pm 491,15 \mathrm{mg} / \mathrm{dl}$, post-operatif parathormon seviyelerinin ortalama $64,02 \pm 110,72$

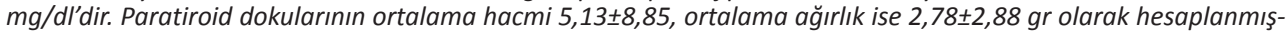
tır. Patolojik tanıları \%83,3'ü adenom, \%10,9'u hiperplazi, \%2,6'sı atipik adenom, \%1,9'u karsinom, \%0,6'sı normal paratiroid ve \%0,6'sı lenf dügüumüdür. Postoperatif PTH seviyesi arttıkça paratiroid bezi ağırlık artısı olduğu ve erkeklerde lezyon ağırlığının daha fazla olduğu gözlendi. Tedaviye tiroidektomi eklenmesi, minimal invaziv yöntem yerine konvansiyonel paratiroidektomi, paratiroid bezinin boyut ve hacminin yüksek olması postoperatif süreçte komplike komplikasyon ile ilișkili saptanmıştır.

Sonuç: Eşlik edebilecek tiroid patolojileri açısından preoperatif olguları iyi değerlendirmek ve tedaviyi minimal invaziv yöntemler ile sürdürmek hastanın postoperatif süreçlerde konforu için daha uygun olacaktır. Paratiroid kitlelerine yaklaşımda her zaman multidisipliner bir yaklaşım sergilemek, olgunun klinik, laboratuvar, intraoperatif ve patolojik bulgularının birlikte değerlendirilmesi çok önemlidir.

Anahtar kelimeler: Paratiroid, adenom, atipik, paratiroid karsinomu, neoplazi, parathormon

(C) Telif hakkı TC. Sağlık Bakanlı̆̆ İmir Tepecik Eğit. ve Arașt. Hastanesi. Logos Tıp Yayınclık tarafindan yayınlanmaktadır.

Bu dergide yayınlanan bütün makaleler Creative Commons Atff-GayriTicari 4.0 Uluslararası Lisansı ile lisanslanmıştr.

(c) Copyright Association of Publication of the T.C. Ministry of Health İzmir Tepecik Education and Research Hospital.

This journal published by Logos Medical Publishing.

Licenced by Creative Commons Attribution-NonCommercial 4.0 International (CC BY) 


\section{INTRODUCTION}

Normal parathyroid gland is generally $5 \times 3 \times 1 \mathrm{~mm}$ in size, and weighs less than $50 \mathrm{mg}{ }^{(1)}$. Five cell types were histologically determined in parathyroid tissue; chief cell, clear/vacuole chief cell, dark chief cell, oxyphil cell, transitional oxyphil cells. Adenomas occur as a result of hyperplasia of one or more of these cells ${ }^{(2)}$.

Parathyroid tumors are heterogeneous tumors with an incidence of $0.1-0.3 \%$ in the general population ${ }^{(3)}$. Generally, $85 \%$ of the cases have single parathyroid adenoma, $10 \%$ have hyperplasia and $3 \%$ have double adenoma. Atypical parathyroid adenomas (APAs) and parathyroid carcinomas (PCS) are extremely rare aggressive endocrine tumors, accounting for less than $1 \%$ of all cases with primary hyperparathyroidism ${ }^{(3-5)}$. PCs occur less than 1 in 1 million people a year (4). In this study it is aimed to evaluate the clinical, laboratory and histopathological characteristics of patients who underwent parathyrodectomy in our hospital in the last 5 years.

\section{MATERIAL and METHODS}

A total of 156 patients who underwent parathyroidectomy and were evaluated in the pathology department between 2015-2020 at the University of Health Sciences Tepecik Training and Research Hospital were included in the study. Age, gender, parathyroid hormone results and pathology reports of the cases were obtained from the hospital information management system and patient files. The cases were grouped according to the ages of the cases as follows: Group 1, $\leq 59$; Group 2, 60-69, nad Group 3, $\geq 70$ years. The patients were grouped according to the types of operations performed as those who underwent only parathyroid excision or partial/total excision of the thyroid together with parathyroidectomy. Among resection materials containing fragmented and/or multiple parathyroid tissue particles, the largest specimen was included in the study, while the data concerning the weights of all specimens were included in the analysis. In order to ensure homogenization of the data concerning the size of the particles, data expressed in centimeters (cm) were converted into 3 dimensional measurements of the volume $\left(\mathrm{cm}^{3}\right)$. VATS and TOEPVA performed were grouped as "other" category. Mediastinal, posterior tracheal and intrathyroidal parathyroid tissues were also grouped in the category of "other" localizations.

SPSS 15.0 Package program (SPSS Inc. Released 2006. SPSS for Windows, Version 15.0. Chicago, SPSS Inc.) was used for statistical analysis and analyzes were made within 95\% confidence interval. One Way ANOVA and $t$ test for independent variables were used in the analysis; $p$ values less than 0.05 were considered to be statistically significant.

\section{RESULTS}

The study population consisted a total of 156 cases including 131 (84\%) female and 25 (16\%) patients. The mean age of the patients was $53.8 \pm 13.5$ (18-92) years. Group 1 constituted of 110 (70.5\%), Group 2, 26 (16.7\%), and Group 3, 20 (12.8\%) cases. Clinical diagnosis of adenoma was made in 144 (92.3\%) and hyperparathyroidism in $12(7.7 \%)$ patients. There is no additional disease in $75 \%$ (117) of the cases while there were concomitant thyroid follicular nodular disease in $21.1 \%$ (33, chronic renal disease in $1.9 \%$ (3), renal transplantation in $1.3 \%$ (2) and thyroid carcinoma in $0.6 \%$ of the cases (1).

When the cases were examined clinically, it is noteworthy that $14.8 \%$ (23) of the cases were ASA1, $69.9 \%$ (109) ASA2, $15.4 \%$ (24) ASA3 in the preoperative evaluation. The mean pre-operative parathyroid hormone levels of the cases were calculated as $415.2 \pm 491.2 \mathrm{mg} / \mathrm{dl}$ (min: $77.8 \mathrm{mg} / \mathrm{dl}$, max: $2348.0 \mathrm{mg} / \mathrm{dl}$ ), while the mean post-operative parathyroid hormone levels were $64.0 \pm 110.7 \mathrm{mg} / \mathrm{dl}$ (min: $0.7 \mathrm{mg} / \mathrm{dl}$, max: $1163.0 \mathrm{mg} / \mathrm{dl}$ ).

Regarding the operation type, $67.9 \%$ (106) of the cases underwent parathyroidectomy independent of the number of glands, and $31.1 \%$ of them 
parathyroidectomy+hemi/total thyroidectomy operation. The operation type of the patients was minimally invasive parathyroidectomy in 19.2\% (30), conventional parathyroidectomy in $78.2 \%$ (122), and the other surgeries in $2.6 \%$ (4) of the cases. Bilateral exploration was performed in $28.2 \%$ (44) of the cases. The excised parathyroid glands were located on the right side in $53.2 \%$ (83), left side in $38.5 \%$ (60) and bilaterally in $3.8 \%(6)$ of the cases. In the axial plane, it was observed that parathyroid glands were localized superiorly in $9.6 \%(15)$, inferiorly in $75.0 \%$ (115), superoinferiorly in $7.7 \%(12)$ of the cases. While $3.5 \%$ (5) of them were located in the middle of the thyroid gland, and $2.6 \%$ (4) of them were located outside these abovementioned regions (mediastinal,

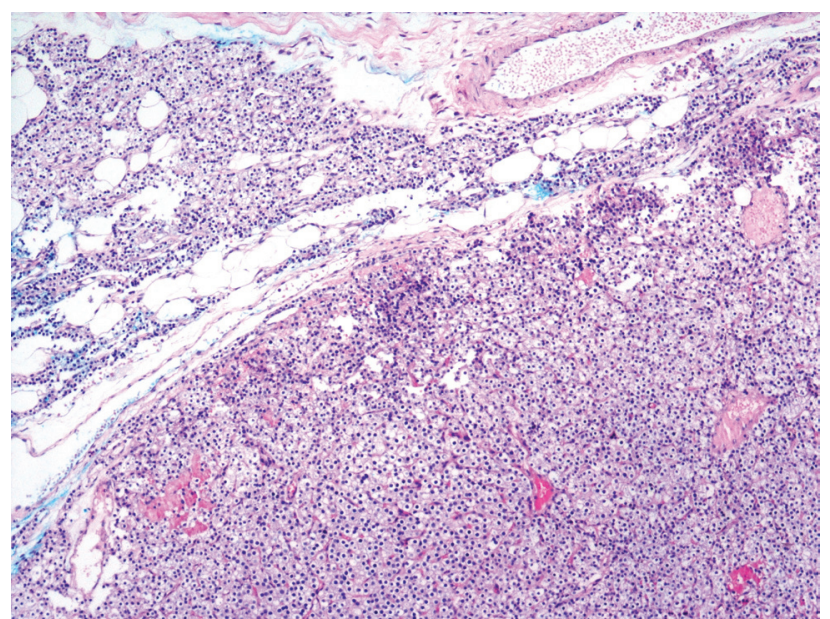

Figure 1. Parathyroid adenoma with normal parathyroid tissue at a rim (H\&E, x100).

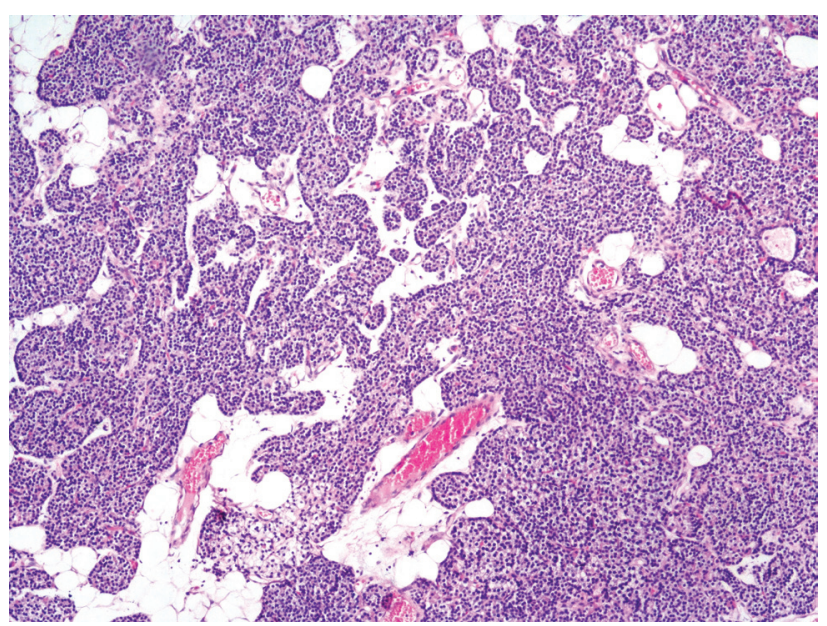

Figure 2. Parathyroid hyperplasia (H\&E, x100). posttracheal, intrathyroidal); It was also determined that localisations of $1.9 \%$ (3) of the lesions was unknown.

In the pathological examination of excised parathyroid tissues, the mean volume was calculated as $5.13 \pm 8.85$ $\mathrm{cm}^{3}$ (min: $0.1 \mathrm{~cm}^{3}$, max: $67.4 \mathrm{~cm}^{3}$ ) and the mean weight as $2.78 \pm 2.88 \mathrm{~g}$ (min: $0.2 \mathrm{~g}$, max: $14.0 \mathrm{~g}$ ). When the pathology reports were examined, adenoma was detected in $83.3 \%$ (130), hyperplasia in $10.9 \%$ (17), atypical adenoma in $2.6 \%$ (4) , carcinoma in $1.9 \%$ (3), normal parathyroid tissue in $0.6 \%$ (1) and lymph node in $0.6 \%$ (1) of the cases. The rates of adenoma, hyperplasia, atypical adenoma and carcinoma are demonstrated in Figure 1-4. Data

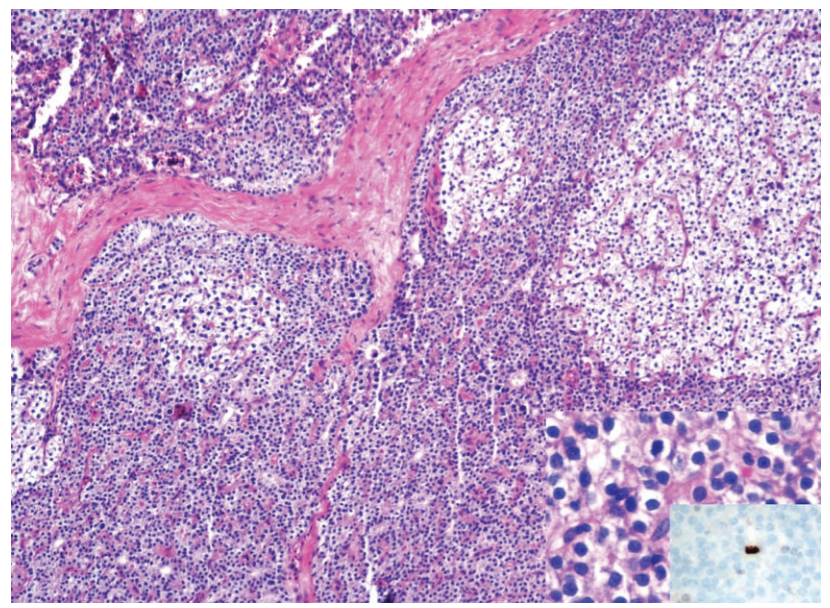

Figure 3. Increased mitosis in atypical parathyroid adenoma (H\&E and PHH3 immunhistochemistry $\times 400$ ), and thick fibrous bands within the adenoma (H\&E, $x 100)$.

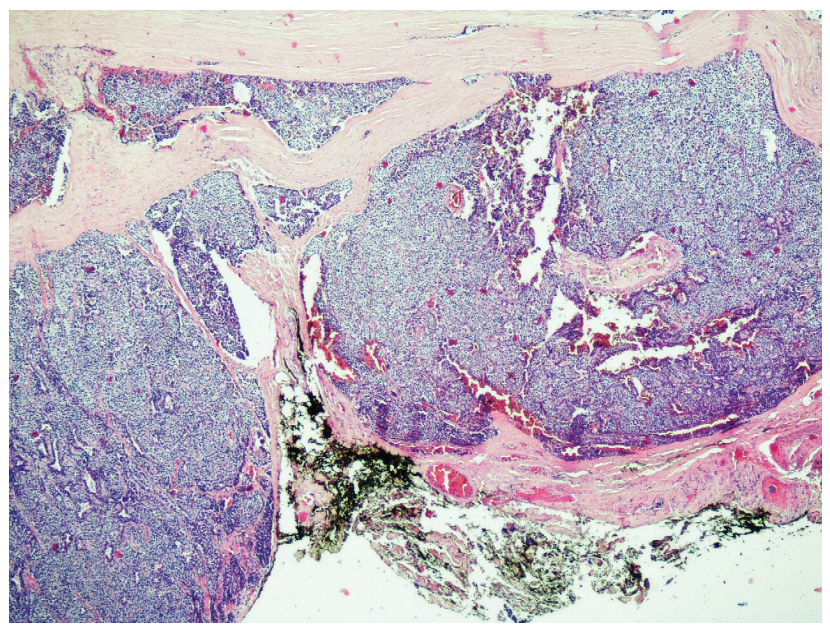

Figure 4. Parathyroid carcinoma (H\&E, x40). 
Table 1. Mean age, gender, size, weight, preoperative and postoperative PTH values according to parathyroid pathologies of the cases (* there is only one value in the group).

\begin{tabular}{lcccccc}
\hline & Age & Gender F/M (\%) & Size $\left(\mathbf{c m}^{3}\right)$ & Weight $(\mathbf{g})$ & Preoperative PTH (mg/dl) & Postopertative PTH (mg/dl) \\
\hline Hyperplasia & $44.6+13.9$ & $76.5-23.5$ & $3.8+4.3$ & $2.7+2.1$ & $864.7+816.0$ & $114.0+292.0$ \\
Adenoma & $54.8+12.9$ & $85.4-14.4$ & $4.1+5.5$ & $2.6+2.6$ & $232.3+355.5$ & $54.6+56.4$ \\
Atypical adenoma & $59.5+22.2$ & $75.0-25.0$ & $6.5+3.4$ & $3.2 *$ & $828.7+689.4$ & $65.7+107.9$ \\
Carcinoma & $53.0+15.1$ & $66.7-33.3$ & $54.5+15.7$ & $12.0+0.0$ & $1319.7+760.0$ & $115.6+163.7$ \\
\hline
\end{tabular}

concerning the mean age, gender, size, weight and PTH values of the cases with pathological parathyroid diagnoses are presented in Table 1 . In addition to diagnoses of parathyroid pathologies, the cases that underwent partial/total thyroid excision had the diagnosis of thyroid follicular nodular disease in 9.6\% (15), papillary microcarcinoma in $7.7 \%$ (12), papillary carcinoma in $3.2 \%$ (5), lymphocytic thyroiditis in $1.9 \%$ (3) of the cases .

When the postoperative processes of the cases were examined, it was determined that various complications developed in $13.5 \%$ (21) of the cases. The mean length of stay in the hospital was $4.9 \pm 4.3$ (min: 1, max: 37) days. While no morbidity was observed in $81.4 \%$ (127) of the cases, unilateral vocal cord paralysis was detected in $6.4 \%$ (10), persistent hypercalcemia in $1.3 \%$ (2) and hypocalcemia in $1.3 \%$ (2) of the cases during clinical follow-up. In addition, it was reported that vision loss, leg contraction, bilateral vocal cord paralysis, recurrent nerve injury, neck hematoma, emphysema, bilateral periorbital edema, nasopharyngeal carcinoma, and vocal bifurcation developed despite normal ENT examination in one case $(0.6 \%)$ in each. In the clinical follow-ups, it was determined that one patient had relapse 6 months later and 1 (0.6\%) patient died.

Statistical analysis did not reveal any statistical significance between preoperative PTH levels and parathyroid weight and volume $(p=0.19, p=1.00$, respectively). Similarly, while there was no statistically significant difference between postoperative PTH values and volume $(p=0.84)$, it was observed that weight of the parathyroid gland increased significantly as postoperative PTH level increased $(p=0.007)$.
There was no significant correlation between age groups and parathyroid volume, weight, pre-and post-operative PTH levels $(p=0.93, p=0.73, p=0.27$, and $p=0.74$, respectively). Similarly there was no correlation between gender and lesion volume, preand post-operative PTH levels $(p=0.07, p=0.68$, and $p=0.74$, respectively). However, a significant relationship was found between gender and weight of the lesion ( $p=0.02)$, and it was noted that weight of the lesion was statistically higher in males.

When adenoma and hyperplasia were compared, no difference was found in terms of lesion volume and weight $(p>0.05)$. On the other hand pre-, and postoperative PTH values were statistically significantly higher in the hyperplasia group $(p=0.000$, and $p=0.047$, respectively).

There was no statistically significant relationship between the complicated cases and gender $(p=0.33)$, age group $(p=0.17)$, comorbidity $(p=0.71)$, pathological diagnosis $(p=0.65)$, additional pathological diagnosis $(p=0.13)$, ASA scores $(p=0.80)$, preoperative PTH $(p=0.65)$ and postoperative PTH levels $(p=0.41)$. However, a statistically significant relationship was observed between complicated cases and operation types $(p=0.005$ and $p=0.003)$ weight $(p=0.009)$ and volume $(p=0.044)$ of the gland. According to these data, it was revealed that the extend of the operation area and the increase in the size of the lesion significantly increased the risk of complications. It was observed that additional synchronous thyroidectomy and using conventional methods increased the risk of complications. Finally, it was noted that there was no statistically significant relationship between the pathological diagnoses of the cases and the duration of hospitalization $(p=0.07)$. 


\section{DISCUSSION}

Parathyroid adenoma is the most common cause of primary hyperparathyroidism ${ }^{(2,6)}$. Adenomas usually occur in one gland ${ }^{(1,2)}$ and although adenomas can originate from any of the 4 parathyroid glands, they most frequently originate from the lower glands ${ }^{(6)}$. Although double adenomas have been reported, single gland involvement is usually seen ${ }^{(6)}$. Adenomas seen with a female/male ratio of $3 / 1$ are macroscopically in the form of nodular masses with or without a thin capsule ${ }^{(2,6)}$. Adenomas can be in different sizes and weights ${ }^{(6)}$. Adenomas with their largest diameters ranging from 1 to $3 \mathrm{~cm}$, and wieghing more than approximately $150 \mathrm{mg}$ have been reported ${ }^{(6)}$. Unlike adenomas, parathyroid hyperplasia can be defined as the proliferation of parenchymal cells in multiple glands ${ }^{(1,6)}$.

When pleomorphic and bizarre nuclei are seen in adenomas, and mitosis and lymphovascular invasion are not observed, this pathology is defined as atypical parathyroid adenoma ${ }^{(2)}$. Atypical parathyroid adenomas are parathyroid neoplasms of uncertain malignant potential and include atypical histological findings that are histologically differentiated from parathyroid carcinomas ${ }^{(3)}$. The question of whether atypical parathyroid adenomas could represent an early stage of a parathyroid carcinoma that was excised prior to the development of the molecular signature of the malignancy responsible for the invasive features, has not been clarified yet ${ }^{(3)}$. According to the histopathological criteria recommended by WHO, the diagnosis of malignancy in the parathyroid gland is made based on the presence of clear and definite signs of invasive growth, vascular invasion, perineural invasion and/ or metastases in adjacent soft tissues or thyroid gland ${ }^{(3)}$.

Parathyroid carcinomas, on the other hand, are extremely rare with an annual incidence of less than 1 in 1 million ${ }^{(4,6)}$ and they are generally sporadic ${ }^{(7)}$. Mutations of the CDC73 gene encoding parafibromin are the most common genetic changes ${ }^{(3,5)}$ in these tumors whose etiology is not clearly known ${ }^{(5,8,9)}$. Although they can be seen clinically at any age, they peak around the age of $50^{(2,10)}$. They often occur equally in women and men ${ }^{(4)}$. Most parathyroid carcinomas (>90\%) secrete parathormone ${ }^{(4,6)}$. The most important feature of PCs is their high recurrence rate ${ }^{(7)}$ and $1 / 3$ of them are known to metastasize ${ }^{(6)}$. PCs are macroscopically large tumors; they usually involve one gland and the most important surgical finding is invasion into adjacent neck tissues ${ }^{(6)}$. Levels of parathyroid hormone are 3 times higher upper limit of normal Tumors over $3 \mathrm{~cm}$, prominent bone and/or kidney involvement, hoarseness and/or neck pain are clinically supporting findings for parathyroid carcinoma ${ }^{(4)}$. However, the definitive diagnosis can be made by histopathological examination. When examining parathyroidectomy materials, detailed clinical information and careful pathological examination are required ${ }^{(7)}$.

Observational studies are very important in terms of characterization of parathyroid lesions, which are not prevalent in the general population. In this context, in one of the studies conducted with a large number of cases, 375 cases who underwent parathyroidectomy were analyzed and 12 cases with adenoma or carcinoma were retrospectively screened (10). The pathological diagnoses of the cases included in the study were reported as PC in 4, parathyroid neoplasm in 5, and parathyroid neoplasm of undetermined malignant potential in 3 cases ${ }^{(10)}$. The mean preoperative parathyroid hormone value of PC cases was stated to be $144.66( \pm 91.73) \mathrm{pg} / \mathrm{mL}$ in this case series with an age range reported as 41-68 years ${ }^{(10)}$. In our study, the mean preoperative PTH values in parathyroid carcinoma $(1319.7 \pm 760 \mathrm{mg} /$ $\mathrm{dl})$, atypical adenoma (828.7 $\pm 689.4 \mathrm{mg} / \mathrm{dl})$, $(323.3 \pm 355.5 \mathrm{mg} / \mathrm{dl})$, and hyperplasia $(864.7 \pm 816.0$ $\mathrm{mg} / \mathrm{dl}$ ) were detrmined as indicated.

In another large case study, Kır et al. examined the clinical, demographic and laboratory findings of patients with primary hyperparathyroidism ${ }^{(11)}$. In the study in which 217 cases were evaluated retrospectively, adenoma had been diagnosed in 
$74.2 \%$, hyperplasia in $23 \%$, while normal parathyroid tissue had been observed in $2.8 \%$ of the cases ${ }^{(11)}$. In this study group patients aged between 20 to 79 (median: 52 years) years and $85 \%$ of the cases consisted of female patients ${ }^{(11)}$. In the examination of 136 adenoma cases that were stated to meet the study criteria, it was reported that $29.4 \%$ of the patients were in the 6th decade of their lives and the median of preoperative PTH level was $163.4 \mathrm{pg} / \mathrm{ml}$ (11). In our study, $30.1 \%$ of the patients with adenoma cases were in the 6th decade of their lives while the median preoperative PTH value was $224.9 \mathrm{mg} / \mathrm{dl}$.

In a study involving 12 cases who underwent parathyrodectomy over a 2-year period, 9 (75\%) of the patients were female and the mean age of the cases was $42.5^{(12)}$ years. In $91.6 \%$ of the cases histopathologically diagnosed as adenoma, the average pre-, and post-operative serum calcium (Ca) values were $12.62 \mathrm{mg} / \mathrm{dl}$, and $9.54 \mathrm{mg} / \mathrm{dl}$, and the corresponding mean values for serum phosphorus (P) were $2.39 \mathrm{mg} / \mathrm{dl}$ and $2.98 \mathrm{mg} / \mathrm{dl}$, respectively ${ }^{(12)}$. The limitation of our study is that the $\mathrm{Ca}$ and $\mathrm{P}$ values could not be included in the study, because they were not available in all cases. In our study, the mean pre-, and post-operative PTH values were $323.3 \pm 355.5 \mathrm{mg} / \mathrm{dl}$, and $54.6 \pm 56.4 \mathrm{mg} / \mathrm{dl}$, respectively Kanat et al. reported the average pre-, and postoperative PTH values of their study population as $276 \mathrm{mg} / \mathrm{dl}$ and $50.87 \mathrm{mg} / \mathrm{dl}$, respectively ${ }^{(12)}$. In the same study, it was reported that the macroscopic diameters of pathological lesions ranged between 7-30 mm (median: $13.9 \mathrm{~mm}$ ) ${ }^{(12)}$. In our study, the volumes of the lesions were calculated in terms of homogeneous evaluation and the largest diameters of the lesions ranged from $0.1 \mathrm{~mm}$ to $42.0 \mathrm{~mm}$ with a mean volume of $4.1 \pm 5.5 \mathrm{~cm}^{3}$. Weight, another morphological criteria, was found to vary between 0.2-14.0 g (mean: $2.6 \pm 2.6 \mathrm{~g}$ ) in the study.

Papillary carcinoma is the most common thyroid malignancy. It constitutes $85 \%$ of all thyroid carcinomas (13). Coexistence of synchronous parathyroid carcinoma and thyroid carcinoma is known to be extremely rare ${ }^{(13)}$. Different opinions are reported in the literature regarding the coexistence of parathyroid and thyroid pathologies. In one of the relevant studies, it was reported that non-medullary thyroid cancers accompanied primary hyperparathyroidism more frequently than the normal population ${ }^{(14)}$. In addition, in this study in which 46 cases who underwent parathyroidectomy were evaluated retrospectively, 35 (76.1\%) cases were reported to have simultaneous thyroidectomy. In the biochemical evaluation of the cases, preoperative serum $\mathrm{P}$ values increased more frequently in the group with microcarcinoma than the other group, and accompanying thyroid pathologies were microcarcinoma in 5 (10.9\%), nodular colloidal goiter in 23, follicular adenoma in 3 and lymphocytic thyroiditis in 4 cases ${ }^{(14)}$. Parathyroid pathologies observed in another series of 202 cases, and adenoma was reported in $93.5 \%$, hyperplasia in $3.5 \%$, carcinoma in $3 \%$ of the cases and synchronous thyroidectomy had been performed in $21 \%$ of the cases ${ }^{(15)}$.

Parathyroid pathologies and co-thyroid pathology are observed in a wide range ${ }^{(16)}$. Similarly, the rate of malignancy of the accompanying thyroid lesion is variable, and there is no guideline on how to treat these patients ${ }^{(16)}$.

In a study evaluating 202 cases operated for parathyroid pathology, thyroid pathology was found in 117 (57.9\%) cases in preoperative examinations (16). The preoperative fine needle aspiration biopsies of the cases were reported as malignant in $1.6 \%$, benign in $85.7 \%$ and hurtle cell neoplasia in $9.5 \%$ of the cases ${ }^{(16)}$. Concurrent thyroid surgery was also performed in $80.3 \%$ of the cases in the same study and the final pathology of all cases were reported as papillary microcarcinoma in $10.2 \%$, papillary carcinoma in $2 \%, 5 \%$ Hashimoto thyroiditis in $5 \%$, lymphocytic thyroiditis in $4 \%$, hurtle cell adenoma in $1 \%$, medullary thyroid carcinoma in $0.5 \%$, welldifferentiated thyroid tumor of uncertain malignant potential in $3 \%$ of the cases ${ }^{(16)}$.

In a study including 83 cases who underwent 
simultaneous parathyroid and thyroid operations, papillary carcinoma was found in 5 cases (6\%) including 4 cases with microcarcinomas ${ }^{(17)}$. In the abovementioned study, it was suggested that the surgical evaluation of the nodule in all parathyroidectomy procedures in the presence of preoperative thyroid nodule is important in terms of planning the concurrent surgical procedure ${ }^{(17)}$.

In our study group, there were 2 cases of atypical parathyroid adenoma accompanying thyroid neoplasia, 1 papillary carcinoma and 1 papillary microcarcinoma. Although there was no accompanying thyroid neoplasia in our 3 cases with parathyroid carcinoma, the diagnosis of papillary microcarcinoma or papillary carcinoma was remarkable in $10.9 \%$ of our cases diagnosed with adenoma. Only papillary microcarcinoma of the thyroid gland accompanied parathyroid hyperplasia in $11.8 \%$ of the cases.

Due to the retrospective nature of our study, serum vitamin $D, C$ and $P$ levels could not be measured and radiological findings could not be evaluated in all cases. Although this constitutes an important limitation in our study, our case series study is considered to be an important trial in that it represents the general population of all parathyroidectomy patients. In our study, it was found that as the weight of parathyroid gland increases, postoperative PTH values also increase and it was also noticed that the weight of the lesion was higher in males. When parathyroid adenoma and hyperplasia were compared, pre-and postoperative PTH values were found to be significantly higher in the hyperplasia group. It is thought that this situation is caused by the diffuse hyperplasia and the possibility of residual tissue remaining postoperatively. It is thought that the effect of the extend of the surgical field together with the size of the lesion determines the relationship between complications, weight, and volume of the parathyroid gland. Considering these data, it is suggested that the determination of the nature of the thyroid lesion by performing a detailed radiological examination, and in case of need fine needle aspiration biopsy in the preoperative period and not resecting the thyroid gland during the parathyroidectomy-because benign lesions do not require intervention-will decrease the risk of complications.

In conclusion, a multidisciplinary management in the approach to parathyroid masses together with evaluation of the clinical, laboratory, intraoperative and pathological findings of the cases is critically important.

Ethics Committee Approval: Approval of the Ethics Committee of University of Health Sciences, Izmir Tepecik Research and Training Hospital was obtained (2021/1/4).

Conflict of Interest: No conflict of interest was declared by the authors.

Funding: The authors declared that this study has received no financial support.

Informed Consent: Since our study was retrospective, consent was not obtained from the patients.

\section{REFERENCES}

1. Guilmette J, Sadow PM. Parathyroid Pathology. Surg Pathol Clin. 2019;12(4):1007-19. [CrossRef]

2. Demiralay E, Altaca G, Demırhan B. Morphological Evaluation of Parathyroid Adenomas and Immunohistochemical Analysis of PCNA and Ki-67 Proliferation Markers. Turk Patoloji Derg. 2011;27(3):215-20. [CrossRef]

3. Cetani F, Marcocci C, Torregrossa L, Pardi E. Atypical parathyroid adenomas: challenging lesions in the differential diagnosis of endocrine tumors. Endocr Relat Cancer. 2019;26(7):R441-R64. [CrossRef]

4. Duan K, Mete Ö. Parathyroid Carcinoma: Diagnosis and Clinical Implications. Turk Patoloji Derg. 2015;31(Suppl 1):8097. [CrossRef]

5. Cao H, Wang W. Case report: a camouflaged parathyroid carcinoma with initial misdiagnosis. BMC Surg. 2019;19(1):175. [CrossRef]

6. Baloch ZW, LiVolsi VA. Pathology of the parathyroid glands in hyperparathyroidism. Semin Diagn Pathol. 2013;30(3):16577. [CrossRef]

7. Quaglino F, Manfrino L, Cestino L, et al. Parathyroid Carcinoma: An Up-to-Date Retrospective Multicentric Analysis. Int J Endocrinol. 2020;2020:7048185. [CrossRef]

8. Aydoğdu A, Meriç C, Yıldız R, et al. Paratiroid kanser olgusu. Gülhane Tıp Derg. 2011;53:139-42.

9. Wei $\mathrm{CH}$, Harari A. Parathyroid Carcinoma: Update and Guidelines for Management. Current Treatment Options in Oncology. 2012;13:11-23. [CrossRef]

10. Erdoğan A, Çetinkaya E, Erdoğan $K$, et al. A Single Center 
Experience of Parathyroid Carcinoma Which Is Less Common Among Parathyroid Tumors. Acta Oncologica Turcica. 2019;52(1):38. [CrossRef]

11. Kır S, Polat C. Primary Hyperparathyroidism: A Single-Center Experience. Turkiye Klinikleri J Med Sci. 2020;40(1):37-45. [CrossRef]

12. Kanat BH, Bozan B, Özkan Z, et al. Düşük yoğunluklu bir merkezde paratiroidektomi deneyimi. Endokrinolojide Diyalog. 2015;12(1):25-9.

13. Lam-Chung CE, Rodríguez-Orihuela DL, González JDA, Gamboa-Domínguez A. An Unusual Simultaneous Existence of Parathyroid Carcinoma and Papillary Thyroid Carcinoma: Case Report and Review of Literature. Case Rep Endocrinol. 2020;2020:2128093. [CrossRef]

14. Kutlutürk K, Otan E, Yağcı MA, Usta S, Aydın C, Ünal B.
Thyroid pathologies accompanying primary hyperparathyroidism: a high rate of papillary thyroid microcarcinoma. Ulus Cerrahi Derg. 2014;30(3):125-8. [CrossRef]

15. Yabanoğlu H, Kuş M, Bağır GŞ, Sarı R, Çolak ii, Arer IM. Yirmi yıllık primer hiperparatiroidi deneyimi: 202 hastanın tedavi sonuçları. Endokrinolojide Diyalog. 2019;16(1):915.

16. Simsek B, Guldogan CE, Ozden S, Saylam B, Karabeyoglu SM, Tez M. Concomitant thyroid cancer in patients with primary hyperparathyroidism in an endemic goitre region. Ann Ital Chir. 2017;88:15-9.

17. Emirikçi S, Özçınar B, Öner G, et al. Thyroid cancer incidence in simultaneous thyroidectomy with parathyroid surgery. Ulus Cerrahi Derg. 2015;31(4):214-7. [CrossRef] 